\title{
Proteomic profile of saliva and plasma from women with impalpable breast lesions
}

\author{
LUCAS DELMONICO ${ }^{1-3}$, MARYAH BRAVO ${ }^{1,3}$, RAFAELE TAVARES SILVESTRE ${ }^{1-3}$, \\ MARIA HELENA FARIA ORNELLAS ${ }^{2,3}$, CAROLINA MARIA DE AZEVEDO $^{4}$ and GILDA ALVES ${ }^{1-3}$
}

\author{
${ }^{1}$ Research Coordination, National Cancer Institute, Rio de Janeiro 20230-130; ${ }^{2}$ Graduate Program of Medical Sciences; \\ ${ }^{3}$ Circulating Markers Laboratory, Faculty of Medical Sciences, State University of Rio de Janeiro, Rio de Janeiro 20550-170; \\ ${ }^{4}$ Department of Radiology, Gaffrée-Guinle University Hospital, Rio de Janeiro 20270-004, Brazil
}

Received December 15, 2015; Accepted June 10, 2016

DOI: $10.3892 / \mathrm{ol} .2016 .4828$

\begin{abstract}
The present study evaluated the proteomic profile of saliva and plasma from women with impalpable breast lesions using nano-liquid chromatography-quadrupole-time-of-flight (nLC-Q-TOF) technology. Plasma and saliva from patients with fibroadenoma $(n=10)$, infiltrating ductal carcinoma $(n=10)$ and healthy control groups $(n=8)$ were assessed by combinations of inter/intra-group analyses, revealing significant quantitative and qualitative differences. The major differentially-expressed proteins in the saliva of patients compared with the controls were $\alpha 2$-macroglobulin and ceruloplasmin, but the proteins that met the minimum fold-change and P-value cut-offs were leukocyte elastase inhibitor and $\alpha$-enolase, and deleted in malignant brain tumors 1 . Concerning plasma, $\alpha$-2-macroglobulin and ceruplasmin were upregulated, while other proteins such as haptoglobin, hemopexin and vitamin D-binding protein were downregulated compared with the control. The changes in immune, molecular transport and signaling pathways were the most representative in the proteomic profile of the saliva and plasma. This is the first study to describe the proteome of saliva and plasma from the same women with impalpable breast lesions.
\end{abstract}

\section{Introduction}

The detection of impalpable breast lesions by mammography has become more common, accounting for $\sim 25 \%$ of diagnosed breast pathologies (1). The detection of impalpable breast lesions generates questions associated with the nature of the lesion

Correspondence to: Mr. Lucas Delmonico or Dr Gilda Alves, Circulating Markers Laboratory, Faculty of Medical Sciences, State University of Rio de Janeiro, 4 Andar, Rio de Janeiro 20550-170, Brazil

E-mail: lucasdelmonico@gmail.com

E-mail: galvesbrown@gmail.com

Key words: circulating biomarkers, impalpable breast lesions, saliva, plasma, proteomics (benign or malignant) and, consequently, with the conduct of the investigation to be executed. Even with advances in imaging, the requirement for biopsies to determine the origin of the lesion has not been eliminated. Furthermore, the biopsies do not represent the best method of evaluation, as the tumor microenvironment can be heterogeneous and unpredictable (2).

The development of non-invasive techniques would revolutionize the detection of early breast cancer, avoiding the physical and psychological discomfort of patients who are submitted to biopsies (3). Currently, the growing research field of circulating biomarkers present in the body fluids or 'liquid biopsy,' promises to revolutionize the undetected malignant cells or their molecular biomarkers (2,4-6).

Until a few years ago, saliva was considered only a fluid supporting the digestive system and a stimulating factor for release of endogenous enzymes. More recently, saliva has become a new alternative source for biomarkers that can reveal local and systemic diseases (7-9). Saliva is a liquid less complex than blood, but it remains able to contain the same proteins and represent the pathological condition of the individual $(6,10)$.

By contrast, blood has previously been the most studied fluid for biomarker research. The disadvantage of using plasma (blood liquid component) is that it is rich in albumin and other high abundance proteins. However, methods for enrichment of low abundance proteins found in plasma have been developed (11).

As a matter of scientific interest, the proteomic profiles of saliva and albumin-depleted plasma were analyzed in the present study by comparing specimens obtained from patients with impalpable breast lesions and a control group. One-dimensional gel electrophoresis and liquid chromatography (LC), followed by mass spectrometry, were applied. This technique consists in the separation of single particles from complex mixtures, such as saliva and plasma, by a reverse high-pressure liquid in a column. This column is coupled to a mass spectrometer, which will measure the mass-to-charge ratio $(\mathrm{m} / \mathrm{z})$ of charged particles, such as peptides and other compounds (12).

\section{Materials and methods}

Patient selection. Patients were recruited between March 2008 and December 2014 at Instituto Nacional de Câncer (INCA) and Hospital Universitário Gafrée-Guinle (HUGG) in Rio 
de Janeiro, Brazil. Control subjects were recruited between March 2008 and December 2009 in HUGG. Ethics committee approval was obtained for the completion of this study, and all subjects enrolled provided written informed consent. Patients with breast lesions classified as grade 3 or 4 by an experienced radiologist using the Breast Imaging Reporting and Data System (13) were included in the study as cases. Subjects who were evaluated and considered systemically healthy were included as controls. Subjects were excluded from the study if they showed immunodeficiency syndromes or genetic syndromes, or if they had been previously diagnosed as cancer patients and were under treatment. The clinical data of the patients were obtained from the hospital records (Table I). Histological classification was graded according to current (2012) World Health Organization criteria (14), and nuclear grade was defined as grades I-III according to the study by Elston and Ellis (15). The number of individuals enrolled and their histopathological types are shown in Table II.

Study design. For the investigation, the specimens of saliva and plasma were pooled (Table II). For all analyses of saliva and plasma, two pools were evaluated from each tumor group (biological replicates). Fibroadenoma (FBR) specimens composed the pool of benign lesions, while infiltrative ductal carcinoma (IDC) specimens (luminal A and B) composed the pool of malignant breast lesions.

Saliva and plasma collection. Saliva was collected as previously described (8). Saliva $(\sim 1 \mathrm{ml})$ was collected and homogenized with $1 \mathrm{mM}$ phenylmethylsulfonyl fluoride (Sigma-Aldrich, St. Louis, MO, USA) and $1 \mathrm{mM}$ ethylenediamine tetraacetic acid (EDTA; Sigma-Aldrich). The samples were kept on ice and, as soon as possible, were centrifuged at $14,000 \mathrm{x} \mathrm{g}$ for $15 \mathrm{~min}$ at $4^{\circ} \mathrm{C}$. The supernatant was transferred to another microtube and homogenized with $1 \mathrm{mM}$ Protease Inhibitor Cocktail (Sigma-Aldrich). The tube was hand shaken and stored at $-80^{\circ} \mathrm{C}$.

Blood samples $(5 \mathrm{ml})$ were obtained from each subject by venipuncture and collected into evacuated tubes containing EDTA as an anticoagulant, and plasma samples were separated by centrifugation at $1,000 \times \mathrm{g}$ for $10 \mathrm{~min}$ at $25^{\circ} \mathrm{C}$. The plasma samples were transferred to $1.5-\mathrm{ml}$ tubes, homogenized with $1 \mathrm{mM}$ Protease Inhibitor Cocktail (Sigma-Aldrich) and preserved at $-80^{\circ} \mathrm{C}$.

Sample preparation and SDS-PAGE. Plasma specimens were enriched by depletion of albumin using Cibracon blue column (Sigma-Aldrich), according to the manufacturer's protocols. The enriched product was stored at $-80^{\circ} \mathrm{C}$ until analysis. The saliva and plasma protein concentrations were measured using the bicinchoninic acid (BCA) or Smith reagent methods (Pierce BCA Protein Assay kit; Pierce Biotechnology, Inc., Rockford, IL, USA) (16). Subsequently, specimens were pooled, according to the histopathological classification (Table I) to a total of $20 \mu \mathrm{g}$, which was loaded in Amersham enhanced chemiluminescence high resolution gels (GE Healthcare Life Sciences, Chalfont, UK), with a concentration of 4-20\%. After the run, the SDS-PAGE gels were stained with Coomassie Blue R-250 (Sigma-Aldrich), according to the manufacturer's instructions.
In gel digestion. Each lane of the gel was divided into slices of 2-5 $\mathrm{mm}$ and washed with $25 \mathrm{mM}$ ammonium bicarbonate in $50 \%$ acetonitrile (ACN; Sigma-Aldrich), overnight at room temperature, to destain the proteins. The slices were then dehydrated in $100 \% \mathrm{ACN}$ for $10 \mathrm{~min}$ and dried completely in a speed-vac centrifuge (Thermo Fisher Scientific Inc., Waltham, MA, USA). The gel fragments were immersed in $10 \mu \mathrm{l}$ of the digestion buffer containing trypsin (modified sequencing grade; Promega Corporation, Madison, WI, USA) at a final concentration of $10 \mathrm{ng} / \mu \mathrm{l}$ in $25 \mathrm{mM}$ ammonium bicarbonate.

The gel fragments were digested with trypsin for $16 \mathrm{~h}$ at $37^{\circ} \mathrm{C}$. The resulting tryptic peptides were extracted from the gel pieces by incubating with $50 \mu \mathrm{l}$ of $50 \% \mathrm{ACN}$ in $5 \%$ trifluoroacetic acid (TFA; Tedia Co., Inc., Fairfield, OH, USA), twice for 15 min each, with agitation. Supernatants were transferred, pooled and concentrated as previously described (17). Each sample was then diluted with $10 \mu \mathrm{l}$ of water in $0.1 \%$ TFA to produce the final volume of digested ultrafiltrate sample (DIUs).

Analysis of DIUs by nano-LC-quadrupole-time-of-flight ( $n L C-Q-T O F)$. Prior to the nLC-Q-TOF analysis, the DIUs underwent manual desalination Zip Tip (Eppendorf, Hamburg, Germany). Each Zip Tip was activated with $10 \mu \mathrm{l}$ ACN and washed three times with $10 \mu \mathrm{l}$ ultrapure sterile water, and then a $10 \mu \mathrm{l}$ sample was loaded by pipetting up and down 10 times within the tube. Each Zip Tip was subsequently washed three times with water and ACN elution was performed. Following this, the samples were reduced to a final volume of $20 \mu \mathrm{l}$ in a speed-vac centrifuge (Thermo Fisher Scientific Inc.) and stored at $-20^{\circ} \mathrm{C}$ until mass spectrometry analysis (Q-TOF Ultima Global; Waters Corporation, Wilmslow, UK).

The resulting peptides were loaded into an electrospray ionization Q-TOF mass spectrometer (Waters Corporation). The DIU samples were loaded onto the Waters nanoACQUITY UPLC ${ }^{\circledR}$ System (Waters Corporation) with a Waters Opti-Pak C18 trap column coupled to Q-Tof Ultima ${ }^{\circledR}$ (Waters Corporation). Subsequently, a 3.0- $\mu 1$ sample was injected into a nanoEase C18 150-mM x 75- $\mu \mathrm{m}$ column (Waters Corporation) at a flow rate of $0.6 \mu \mathrm{l} / \mathrm{min}$, and eluted with $\mathrm{ACN}$ containing $0.1 \%$ formic acid.

The instrument control and data acquisition were performed using a MassLynx data system (version 4.0; Waters Corporation). The experiments were performed by scanning from a mass-to-charge ratio of between 200 and 2,000. The exact mass was automatically determined using the Q-Tof's LockSpray $^{\mathrm{TM}}$ (Waters Corporation).

Database searching. The data generated by the MassLynx data system (version 4.0; Waters Corporation) were imported, and all MS/MS samples were analyzed using Mascot (version 2.3.02; Matrix Science, London, UK). The following parameters were used to search the database: i) Taxonomy; ii) peptide by digestion with a trypsin cleavage site allowed; iii) carbamidomethylation as fixed modification; d) and oxidation as varied modification. The proteins were identified by the correlation of tandem mass spectra to the NCBInr proteins and MSDB database, using MASCOT online software (www.matrixscience.com). For protein quantification, the data files were analyzed by Scaffold Q+ (version 4.4.3; Proteome 
Table I. Clinical data of the cases evaluated in this study.

\begin{tabular}{|c|c|c|c|}
\hline Characteristics & $\operatorname{FBR}(n=10)$ & IDC $(n=10)$ & Control $(n=8)$ \\
\hline Mean age $\pm S D$, years & $41.3 \pm 16.3$ & $49.7 \pm 14.7$ & $47.4 \pm 8.0$ \\
\hline \multicolumn{4}{|l|}{ Ethnicity $^{\mathrm{a}}, \mathrm{n}(\%)$} \\
\hline White & $7(70.0)$ & $3(30.0)$ & $7(87.5)$ \\
\hline Black/Mixed & $1(10.0)$ & $3(40.0)$ & $1(12.5)$ \\
\hline NI & $2(20.0)$ & $4(40.0)$ & $0(0.0)$ \\
\hline \multicolumn{4}{|l|}{ Menarche, n (\%) } \\
\hline$\leq 12$ years & $4(40.0)$ & $3(30.0)$ & $5(62.5)$ \\
\hline$>12$ years & $4(40.0)$ & $4(40.0)$ & $3(37.5)$ \\
\hline NI & $2(20.0)$ & $3(30.0)$ & $0(0.0)$ \\
\hline \multicolumn{4}{|l|}{ Menopause, n (\%) } \\
\hline$<45$ years & $0(0.0)$ & $1(10.0)$ & $2(25.0)$ \\
\hline$\geq 45$ years & $2(20.0)$ & $3(30.0)$ & $3(37.5)$ \\
\hline NI & $1(10.0)$ & $2(20.0)$ & $0(0.0)$ \\
\hline NM & $7(70.0)$ & $4(40.0)$ & $3(37.5)$ \\
\hline \multicolumn{4}{|l|}{ Children, n (\%) } \\
\hline No child & $5(50.0)$ & $3(30.0)$ & $2(25.0)$ \\
\hline 1 & $1(10.0)$ & $2(20.0)$ & $2(25.0)$ \\
\hline 2 & $2(20.0)$ & $1(10.0)$ & $2(25.0)$ \\
\hline$\geq 3$ & $1(10.0)$ & $3(30.0)$ & $1(12.5)$ \\
\hline NI & $1(10.0)$ & $1(10.0)$ & $1(12.5)$ \\
\hline \multicolumn{4}{|c|}{ Oral contraceptive use, n (\%) } \\
\hline Yes & $7(70.0)$ & $3(30.0)$ & $7(87.5)$ \\
\hline No & $1(10.0)$ & $5(50.0)$ & $1(12.5)$ \\
\hline NI & $2(20.0)$ & $2(20.0)$ & $0(0.0)$ \\
\hline \multicolumn{4}{|c|}{ History of breast/ovarian cancer, n (\%) } \\
\hline Yes & $7(70.0)$ & $2(20.0)$ & $4(50.0)$ \\
\hline No & $1(10.0)$ & $5(50.0)$ & $4(50.0)$ \\
\hline NI & $2(20.0)$ & $3(30.0)$ & $0(0.0)$ \\
\hline \multicolumn{4}{|l|}{ Alcoholism, n (\%) } \\
\hline Yes & $4(40.0)$ & $1(10.0)$ & $2(25.0)$ \\
\hline No & $4(40.0)$ & $7(70.0)$ & $6(75.0)$ \\
\hline NI & $2(20.0)$ & $2(20.0)$ & $0(0.0)$ \\
\hline \multicolumn{4}{|l|}{ Smoking, n (\%) } \\
\hline Yes & $1(10.0)$ & $3(30.0)$ & $4(50.0)$ \\
\hline No & $7(70.0)$ & $5(50.0)$ & $4(50.0)$ \\
\hline NI & $2(20.0)$ & $2(20.0)$ & $0(0.0)$ \\
\hline \multicolumn{4}{|c|}{ Lymph node infiltration ${ }^{\mathrm{b}}, \mathrm{n}(\%)$} \\
\hline Yes & - & $5(50.0)$ & - \\
\hline No & - & $2(20.0)$ & - \\
\hline NI & - & $3(30.0)$ & - \\
\hline
\end{tabular}

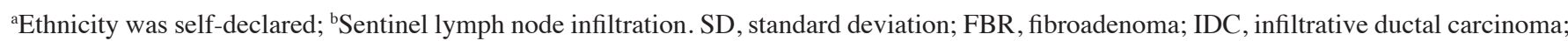
NI, not informed; NM, not menopausal.

Software, Inc., Portland, OR, USA). Protein probabilities were assigned by the Protein Prophet algorithm (18).

Criteria variables were tested to identify the differentially-expressed proteins. In the first analysis, the pools of benign and malignant cases (subgroups) were compared with the control pool. The second time, each individual tumor group was compared with another tumor group. Fisher's exact test was used to account for the sample pairing using the protein analysis program Scaffold Q+ version 4.4.3. A fold-change cut-off of 1.5 and a P-value cut-off of 0.05 , as used by various quantitative proteomic studies (19-22), were used as minimum criteria for differential protein expression. 
Table II. Specimens included in the study.

\begin{tabular}{lccc}
\hline Fluid & FBR & IDC & Controls \\
\hline Saliva, $\mathrm{n}$ & 10 & 10 & 8 \\
Plasma, $\mathrm{n}$ & 10 & 10 & 8
\end{tabular}

FBR, fibroadenoma; IDC, infiltrative ductal carcinoma (luminal A and $\mathrm{B})$.

The proteins present in the saliva and plasma, according to their functional class, were determined by the PANTHER program, version 10.0 (23) (release date May 15,2015,containing 11,928 protein families, divided into 83,190 functionally distinct protein subfamilies; http://www.pantherdb.org/). The construction of the interaction pathways between the differentially-expressed proteins was generated by Integrated System Interactome (24).

\section{Results}

In the quantitative analysis of the saliva, the FBR and IDC groups, exhibited 8 and 9 proteins, respectively, that were differentially-expressed with regard to the control (Table III). The $\alpha$-2-macroglobulin and ceruloplasmin proteins were downregulated in all cases evaluated in comparison with the control group, but the two proteins were upregulated in the FBR group compared with the other case groups. Three other proteins, leukocyte elastase inhibitor, deleted in malignant brain tumors 1 protein and $\alpha$-enolase, were the only proteins that demonstrated isolated cases of overexpression, but that met the minimum established P-value and fold-change cut-offs (Table III).

Concerning the plasma, the analysis of the FBR and IDC groups revealed 6 and 3 proteins, respectively, that were differentially-expressed with regard to the control, respectively. The list of these proteins is shown in Table IV. The $\alpha$-2-macroglobulin protein showed overexpression in all cases in comparison to the control group, and ceruloplasmin showed overexpression in cases of benign lesions. In particular, the vitamin D-binding protein was downregulated in all cases evaluated compared with the control, and when compared between tumor groups, the protein was downregulated in the IDC group.

For the quantitative analysis (considering $\mathrm{P}<0.05$ and fold-change $>1.5$ ), only the $\alpha$-2-macroglobulin, chain B quaternary $\mathrm{R}$ co-liganded hemoglobin structure in complex with the thiol-containing compound, ceruloplasmin, hemopexin and vitamin D-binding proteins showed significant qualitative changes in the plasma (Table IV).

\section{Discussion}

The present study revealed the saliva proteins of women with impalpable breast lesions, reinforcing the idea that saliva is a fluid containing biomarkers that are able to promote the early detection of breast cancer or that even act as a complementary test for the cancer prognosis.
Certain proteins that were identified in the present study have previously been described in the saliva pool from cases of FBR described by Streckfus et al (25). According to the study, the $\alpha$-enolase protein was upregulated in the saliva pool of 10 cases of FBR (25). By contrast, in the saliva pool from the FBR cases, $\alpha$-enolase was found to be downregulated. This difference in expression can probably be explained by the individual/population profiles; for example, tobacco users were included in the present study, while Streckfus et al (25) excluded tobacco smokers. However, the same group $(26,27)$ found the $\alpha$-enolase protein upregulated in the saliva pool of IDC cases [histological grade 2, human epidermal growth factor receptor 2 (HER2)-positive or -negative, and positive sentinel lymph nodes]. The present study results for the IDC tumors (luminal A and B) were in agreement with these findings. Therefore, we suggest that $\alpha$-enolase protein may be associated with early breast carcinogenesis tumors in the majority of breast cancer subtypes (luminal A, luminal B and HER2-positive).

The present study results on proteins, such as deleted in malignant brain tumors 1 and leukocyte elastase proteins, also showed contradictory levels of expression compared with the studies by Streckfus et al $(26,27)$. According to the studies, these proteins showed underexpression in the pool of saliva from women affected with IDC (histological grade 2, negative HER2 receptors and positive sentinel lymph nodes). On the other hand, in the present study, these same proteins were upregulated in the saliva pool of cases with IDCs (luminal A and B). Thus, we believe that the results are incompatible, due to differences in the populations studied.

The other proteins, actin cytoplasmatic 2, $\alpha$-2-macroglobulin, ceruloplasmin, and chain A and B quaternary R co-liganded hemoglobin structure, present in the saliva pool of FRB and IDC cases, exhibited variability in their expression in the intra-group analysis (Table III). The same variability was observed in other studies (25-28). For example, the $\alpha$-2-macroglobulin described in the saliva pool of cases with IDC (histological grade 2, HER2-positive or -negative, and positive sentinel lymph nodes) was upregulated (27), while in the saliva pools of the present study (IDC and FBR) $\alpha$-2-macroglobulin was downregulated.

The proteins present in the saliva and plasma, according to their functional class determined by the PANTHER program version 10.0 , revealed immune system proteins, binding to nucleic acids and transportation proteins (data not shown), which are common among tumors (4,25-30). When observing the interactome, the highlighted proteins were involved in the initial process of carcinogenesis (data not shown), for example, the metalloproteinases and epidermal growth factor receptor (31).

Plasma is the main fluid in the assessment of predictive and prognostic biomarkers for diseases in general. The proteins identified in plasma have contributed to enhancing the molecular classification of breast cancer (32). In the present study, albumin plasma protein was selected for depletion, probably causing fewer proteins to be identified in the plasma specimens as compared with the saliva specimens from the same patients. Thus, we believe that this depletion has affected the results. Other studies have also described that depletion reduced the number of final proteins identified (33-35). 


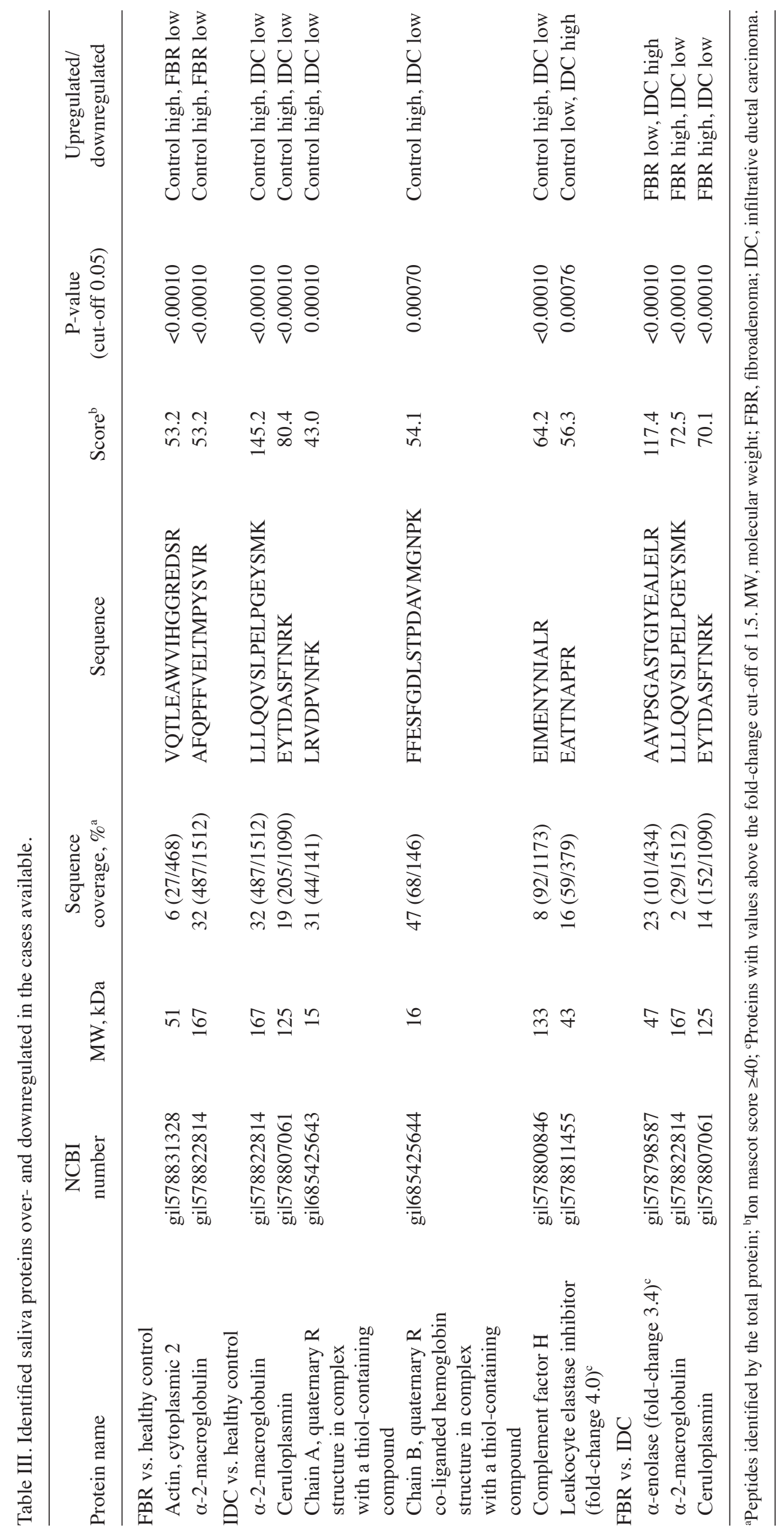




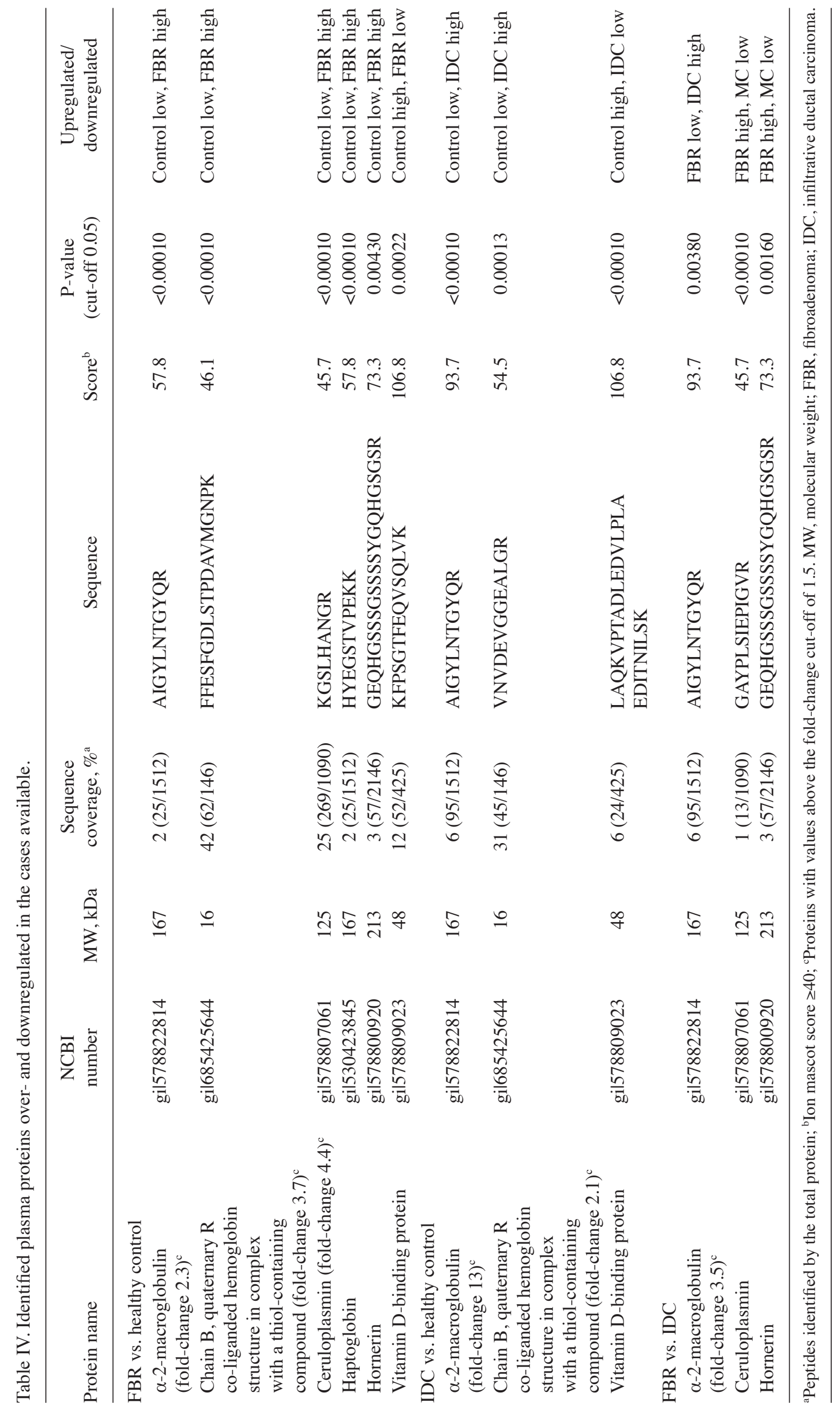


The present study observed that the $\alpha$-2-macroglobulin protein was upregulated in the plasma pool from all groups (FBR and IDC), and that haptoglobin and vitamin D-binding proteins downregulated, in comparison with the controls. Other proteins, including hornerin, haptoglobin, ceruloplasmin and hemopexin, exhibited contradictions in the analysis and differences among groups, but appeared to be upregulated in the plasma pool of the FBR cases (Table IV).

$\alpha-2-$ macroglobulin and ceruloplasmin proteins have previously been identified as downregulated in the plasma of women 21 months prior to the diagnosis of breast cancer (36), as well as in the serum pool of women with IDC (HER2-positive) who were treated with neoadjuvant chemotherapy (37). Moreover, the level of the plasma concentration of $\alpha$-2-macroglobulin and ceruplasmin proteins appeared to be upregulated in the plasma pool of the IDC group in the present study.

Finally, a protein associated with vitamin D transportation was downregulated in all tumor groups (FBR and IDC) that were evaluated in the present study. Vitamin D is extremely important in cancer prevention, acting as an anti-apoptotic, anti-proliferative and anti-tissue invasion agent. In recent studies, the reduction in levels of vitamin D-binding protein has enhanced the risk for developing breast cancer (38), as well as for bladder (39) and pancreatic (40) cancer, and prostate tumors (41).

It is known that in the downregulation of vitamin D receptors in breast epithelial tissue, or even in the reduction of its active form, breast tissue is able to start the process of ductal and branch lengthening, becoming a relative risk for the development of breast cancer $(42,43)$. As determined in the present results, vitamin D-binding protein was downregulated in all breast lesion groups, suggesting that complementation of vitamin D is important for preventing the evolution of and improving the prognosis of breast cancer. However, we believe that supplementation of vitamin D should be reviewed, as the defect may lie in the transportation of vitamin D, as observed in the present study.

There are no well-defined data on the intersection of proteins that have been revealed between saliva and plasma. For example, in the present study, the $\alpha$-2-macroglobulin protein was downregulated in the saliva pool, while in the plasma pool, it displayed overexpression for all groups evaluated (FBR and IDC). The deleted malignant brain tumors 1 protein showed overexpression only in the saliva pool. Thus, we believe that the concentration of a number of these proteins may be fluid-dependent (28).

To the best of our knowledge, this is the first study assessing the proteomics of pools of saliva and plasma from the same cases characterized by impalpable breast lesions. We believe that the study should be continued, comparing the results with other breast cancer subtypes and increasing the number of subjects to validate the proteins that were described in the saliva and plasma.

It is expected that with advances in imaging technologies, the detection of impalpable breast lesions will become increasingly common, and the development of less invasive testing is a real necessity. The proteins found in the present study provide evidence of the molecular changes that are associated with early breast lesions. The cause of the downregulation of vitamin $\mathrm{D}$, as an additional risk factor for breast cancer, should be tracked, considering that the cause may possibly lie in its transportation pathway.

\section{Acknowledgements}

The authors would like to thank Miss Romenia Ramos Domingues and Dr Bianca Alves Pauletti at the Brazilian Biosciences National Laboratory CNPEM (Campinas, Brazil) for providing technical support, and the Mass Spectrometry Facility at the Brazilian Biosciences National Laboratory, CNPEM for their support in the mass spectrometric analysis. This study was supported by Fundação Carlos Chagas Filho de Amparo à Pesquisa do Estado do Rio de Janeiro (APQ1 E-26/110.319/2008 and APQ1 E-26/110.803/2009), and Programa de Oncobiologia, Rio de Janeiro, Brazil.

\section{References}

1. Fusco R, Petrillo A, Catalano O, Sansone M, Granata V, Filice S, D'Aiuto M, Pankhurst Q and Douek M: Procedures for location of non-palpable breast lesions: A systematic review for the radiologist. Breast Cancer 21: 522-531, 2014.

2. Gerlinger M, Rowan AJ, Horswell S, Larkin J, Endesfelder D, Gronroos E, Martinez P, Matthews N, Stewart A, Tarpey P, et al: Intratumor heterogeneity and branched evolution revealed by multiregion sequencing. N Engl J Med 366: 883-892, 2012.

3. Bidard FC, Fehm T, Ignatiadis M, Smerage JB, Alix-Panabières C, Janni W, Messina C, Paoletti C, Müller V, Hayes DF, et al: Clinical application of circulating tumor cells in breast cancer: Overview of the current interventional trials. Cancer Metastasis Rev 32: 179-188, 2013.

4. Bettegowda C, Sausen M, Leary RJ, Kinde I, Wang Y, Agrawal N, Bartlett BR, Wang H, Luber B, Alani RM, et al: Detection of circulating tumor DNA in early-and late-stage human malignancies. Sci Transl Med 6: 224ra24, 2014.

5. Dawson SJ, Tsui DW, Murtaza M, Biggs H, Rueda OM, Chin SF Dunning MJ, Gale D, Forshew T, Mahler-Araujo B, et al: Analysis of circulating tumor DNA to monitor metastatic breast cancer. N Engl J Med 368: 1199-1209, 2013.

6. Zhang L, Xiao H, Karlan S, Zhou H, Gross J, Elashoff D, Akin D, Yan X, Chia D, Karlan B and Wong DT: Discovery and preclinical validation of salivary transcriptomic and proteomic biomarkers for the non-invasive detection of breast cancer. PLoS One 5: e15573, 2010.

7. Burbelo PD, Bayat A, Lebovitz EE and Iadarola MJ: New technologies for studying the complexity of oral diseases. Oral Dis 18: 121-126, 2012.

8. Gonçalves Lda R, Soares MR, Nogueira FC, Garcia C, Camisasca DR, Domont G, Feitosa AC,Pereira Dde A,Zingali RB and Alves G: Comparative proteomic analysis of whole saliva from chronic periodontitis patients. J Proteomics 73: 1334-1341, 2010.

9. Delmonico L, Moreira Ados S, Franco MF, Esteves EB, Scherrer L, Gallo CV, do Nascimento CM, Ornellas MH, de Azevedo CM, Alves G, et al: CDKN2A (p14 (ARF)/p16 (INK4a)) and ATM promoter methylation in patients with impalpable breast lesions. Hum Pathol 46: 1540-1547, 2015.

10. Abraham JE, Maranian MJ, Spiteri I, Russell R, Ingle S, Luccarini C, Earl HM, Pharoah PP, Dunning AM and Caldas C: Saliva samples are a viable alternativeto blood samples as source of DNA for high throughput genotyping. BMC Med Genomics 5: 19, 2012.

11. Prieto DA, Johann DJ JR, Wei BR, Ye X, Chan KC, Nissley DV, Simpson RM, Citrin DE, Mackall CL, Linehan WM and Blonder J: Mass spectrometry in cancer biomarker research: A case for immunodepletion of abundant blood-derived proteins from clinical tissue specimens. Biomark Med 8: 269-286, 2014.

12. Murray KK: Coupling matrix-assisted laser desorption/ionization to liquid separations. In: Mass Spectrometry Reviews. Vol 16. 5th edition. Wiley Periodicals, Inc., Hoboken, NJ, pp283-289, 1997.

13. D’Orsi CJ, Sickles EA, Mendelson EB, Morris EA, Creech WE, Butler PF, Wiegmann PG, Chatfield MB, Meyer LW and Wilcox PA (eds): ACR BI-RADS ${ }^{\circledR}$ Atlas, Breast Imaging Reporting and Data System. 4th edition. American College of Radiology, Reston, VA, 2013.

14. Lakhani SR, Ellis IO, Schnitt SJ, Tan PH and van de Vijver MJ (eds): WHO classification of tumours of the breast. 4th edition. IARC Press, Lyon, 2012. 
15. Elston CW and Ellis IO: Pathological prognostic factors in breast cancer. I. The value of histological grade in breast cancer: experience from a large study with long-term follow-up. Histopathology 41: 154-161, 2002.

16. Smith PK, Krohn RI, Hermanson GT, Mallia AK, Gartner FH, Provenzano MD, Fujimoto EK, Goeke NM, Olson BJ and Klenk DC: Measurement of protein using bicinchoninic acid Anal Biochem 150: 76-85, 1985

17. Delmonico L, Areias VR, Pinto RC, Matos Cda S, Rosa MF De Azevedo CM and Alves G: Protein identification from dried nipple aspirate fluid on Guthrie cards using mass spectrometry. Mol Med Rep 12: 159-164, 2015.

18. Nesvizhskii AI, Keller A, Kolker E and Aebersold R: A statistical model for identifying proteins by tandem mass spectrometry. Anal Chem 75: 4646-4658, 2003.

19. Sethi MK, Thaysen-Andersen M, Kim H, Park CK, Baker MS, Packer NH, Paik YK, Hancock WS and Fanayan S: Quantitative proteomic analysis of paired colorectal cancer and non tumorigenic tissues reveals signature proteins and perturbed pathways involved CRC progression and metastasis. J Proteomics 126: 54-67, 2015.

20. de Wit M, Kant H, Piersma SR, Pham TV, Mongera S, van Berkel MP, Boven E, Pontén F, Meijer GA, Jimenez CR and Fijneman RJ: Colorectal cancer candidate biomarkers identified by tissue secretome profiling. J Proteomics 99: 26-39, 2014.

21. Mirzaei M, Soltani N, Sarhadi E, George IS, Neilson KA Pascovici D, Shahbazian S, Haynes PA, Atwell BJ and Salekdeh GH: Manipulating root water supply elicts major shifts in the shoot proteome. J Proteome Res 13: 517-526, 2014

22. Smit MA, Maddalo G, Greig K, Raaijmakers LM, Possik PA, van Breukelen B, Cappadona S, Heck AJ, Altelaar AF and Peeper DS: ROCK1 is a potencial combinatorial drug target for BRAF mutant melanoma. Mol Syst Biol 10: 772, 2014.

23. Mi H, Lazareva-Ulitsky B, Loo R, Kejariwal A, Vandergriff J, Rabkin S, Guo N, Muruganujan A, Doremieux O, Campbell MJ, et al: The PANTHER database of protein families, subfamilies, functions and pathways. Nucleic Acids Res 33: D284-D288, 2005.

24. Carazzolle MF, de Carvalho LM, Slepicka HH, Vidal RO, Pereira GA, Kobarg J and Meirelles GV: IIS-Integrated interactome system: A web-based platform for the annotation, analyses and visualization of protein-metabolite-gene-drug interactions by integrating a variety of data sources and tools. PLoS One 9: e100385, 2014.

25. Streckfus CF, Mayorga-Wark O, Arreola D, Edwards C, Bigler L and Dubinsky WP: Breast cancer related proteins are present in saliva and are modulated secondary to ductal carcinoma in situ of the breast. Cancer Invest 26: 159-167, 2008.

26. Streckfus CF, Arreola D, Edwards C and Bigler L: Salivary protein profiles among HER2/neu-receptor-positive and -negative breast cancer patients: Support for using salivary protein profiles for modeling breast cancer progression. J Oncol 2012: 413256 2012.

27. Streckfus CF, Storthz KA, Bigler L and Dubinsky WP: A comparison of the proteomic expression in pooled saliva specimens from individuals diagnosed with ductal carcinoma of the breast with and without lymph node involvement. J Oncol 2009: 737619, 2009.

28. Wang J, Liang Y, Wang Y, Cui J, Liu M, Du W and Xu Y: Computational prediction of human salivary proteins from blood circulation and application to diagnostic biomarker identification. PLoS One 8: e80211, 2013.
29. Yang Y, Rhodus NL, Ondrey FG, Wuertz BR, Chen X, Zhu Y and Griffin TJ: Quantitative proteomic analysis of oral brush biopsies identifies secretory leukocyte protease inhibitor as a promising, mechanism-based oral cancer biomarker. PLoS One 9: e95389, 2014.

30. Jehmlich N, Stegmaier P, Golatowski C, Salazar MG, Rischke C, Henke $\mathrm{M}$ and Völker U: Differences in the whole saliva baseline proteome profile associated with development of oral mucositis in headand neck cancer patients undergoing radiotherapy. J Proteomics 125: 98-103, 2015.

31. daRosa MR, Falcão AS, Fuzii HT, da Silva Kataoka MS, Ribeiro AL, Boccardo E, de Siqueira AS, Jaeger RG, de Jesus Viana Pinheiro J and de Melo Alves Júnior S: EGFR signaling downstream of EGF regulates migration, invasion and MMP secretion of immortalized cells derived from human ameloblastoma. Tumour Biol 35: 11107-11120, 2014.

32. Zhang F and Chen JY: Breast cancer subtyping from plasma proteins. BMC Med Genomics 6 (Supply 1): S6, 2013

33. Bandow JE: Comparison of protein enrichment strategies for proteome analysis of plasma. Proteomics 10: 1416-1425, 2010

34. Timms JF, Arslan-Low E, Gentry-Maharaj A, Luo Z, T'Jampens D, Podust VN, Ford J, Fung ET, Gammerman A, Jacobs I and Menon U: Preanalytic influence of sample handling on SELDI-TOF serum protein profiles. Clin Chem 53: 645-656, 2007.

35. van Winden AW, van den Broek I, Gast MC, Engwegen JY, Sparidans RW, van Dulken EJ, Depla AC, Cats A, Schellens JH, Peeters PH, et al: Serum degradome markers for the detection of breast cancer. J Proteome Res 9: 3781-3788, 2010.

36. Opstal-van Winden AW, Krop EJ, Kåredal MH, Gast MC, Lindh CH, Jeppsson MC, Jönsson BA, Grobbee DE, Peeters PH, Beijnen JH, et al: Searching for early breast cancer biomarkers by serum protein profiling of pre-diagnostic serum; A nested case-control study. BMC Cancer 11: 381, 2011.

37. Mazouni C, Baggerly K, Hawke D, Tsavachidis S, André F, Buzdar AU, Martin PM, Kobayashi R and Pusztai L: Evaluation of changes in serum protein profiles during neoadjuvant chemotherapy in HER2-positive breast cancer using an LC-MALDI-TOF/ MS procedure. Proteomics 10: 3525-3532, 2010.

38. Wang J, Eliassen AH, Spiegelman D, Willett WC and Hankinson SE: Plasma free 25-hydroxyvitamin D, vitamin D binding protein and risk of breast cancer in the Nurses' Health Study II. Cancer Causes Control 25: 819-827, 2014.

39. Mondul AM, Weinstein SJ, Virtamo J and Albanes D: Influence of vitamin D binding protein on the association between circulating vitamin D and risk of bladder cancer. Br J Cancer 107: 1589-1594, 2012.

40. Weinstein SJ, Stolzenberg-Solomon RZ, Kopp W, Rager H, Virtamo J and Albanes D: Impact of circulating vitamin D binding protein levels on the association between 25 -hydroxyvitamin D and pancreatic cancer risk: A nested case-control study. Cancer Res 72: 1190-1198, 2012.

41. Weinstein SJ, Mondul AM, Kopp W, Rager H, Virtamo J and Albanes D: Circulating 25-hydroxyvitamin D, vitamin D-binding protein and risk of prostate cancer. Int J Cancer 132: 2940-2947, 2013.

42. Zinser G,Packman K and Welsh J: Vitamin D (3) receptor ablation alters mammary gland morphogenesis. Development 129: 3067-3076, 2002

43. Lopes N, Paredes J, Costa JL, Ylstra B and Schmitt F: Vitamin D and the mammary gland: A review on its role in normal development and breast cancer. Breast Cancer Res 14: 211, 2012. 